\title{
Heavy Metal Pollution: Copper
}

\section{Kuculk $S^{*}$}

Department of Aquacultural Engineering and Fisheries, Adnan Menderes University, Turkey

*Corresponding author: Semra Kucuk, Adnan Menderes University, Faculty of Agriculture, Department of Aquacultural Engineering and Fisheries, 09100 Aydin,

\begin{tabular}{c}
\hline Editorial \\
Volume 1 Issue 5 \\
Received Date: October 23,2018 \\
Published Date: October 30,2018 \\
DOI: $10.23880 /$ izab-16000127 \\
\hline
\end{tabular}

Turkey, Email: skucuk@adu.edu.tr

\section{Editorial}

One of the biggest problems of the world is environmental pollution due to development of technology and increase of population. Heavy metal pollution is one of element of pollution. Heavy metals are released to environment (water and soil) because of industrial, agricultural and mining activities. For example copper sulfate has been used for fungal disease control in viticulture in Portugal and in aquaculture in Turkey. Copper is discovered in the aquatic habitats collecting runoff water from this agricultural area [1]. Cooper is also found in some areas contaminated by domestic wastes such as mining, smithery, waste incinerators, thermal reactors generating power from coal and construction materials used for buildings [2]. Heavy metals accumulate in the aquatic organisms. Especially, it is found that they accumulate in different amount and different tissues of fish. There are many literatures about it [3-6]. Heavy metals enter the food chain in aquatic ecosystems and it increases in it. Then they could be dangerous to human, which is the top of the food chain [7].

Copper is the essential trace metal for all organisms in nature. Since it acts an important role in the fish metabolism such as cellular respiration, free radical defense, neurotransmitter function, and connective tissue biosyntheses. It is also used into structural protein [1]. This heavy metal causes toxicological effects on fish if its concentration is high in the water. Actually, physiological detoxification mechanism works, but if the copper concentration is higher than detoxification capacity, there is nothing to do.

A toxic concentration of copper causes histopathological disorders in fish. For example, copper exposure induces edema, lifting of epithelium cells, intense vasodilation in lamella, additionally lamellar fusion due to proliferation in epithelia and aneurisms in gills and vacuolization and necrosis in liver of tilapia (Oreochromis niloticus) [1]. Copper toxicity provokes also necrosis, hypertrophy, and rupture of gill epithelium and hemorrhage in lamellar cells in 7 day exposure and lifting of epithelium cells, edema, and fusion in 28 day exposure. Decrease in size of liver cells, vacuolization, hypertrophy in liver; fusion of microvillus, change in mucus membrane, cell swolling in intestine; edema, largening of cells in muscle of Asian sea bass (Lates calcarifer) [8].

\section{References}

1. Figueiredo FA, Ferreira CJV, Garcia SS, Monteiro SM, Carrola J, et al. (2007) Histopathological changes in liver and gill epithelium of Nile tilapia, tilapia, Oreochromis niloticus, exposed to waterborne copper. Pesquisa Veterinaria Brassileira 27(3): 103-109.

2. Nor YM (1987) Ecotoxicology of copper to aquatic biota: A review. Environ Res 43(1): 274-282.

3. Ünlu E, Cengiz Eİ, Akba O, Gumgum B (1995) Heavy metal accumulation in Capoeta trutta Heckel, 1843 in Dicle River II National Ecology and Environment Congress, Oral presentation, 11-13 of September, Ankara-Turkey.

4. Çalta M, Canpolat Ö, Nacar A (2000) Determination of heavy metal levels of Capoeta trutta (HECKEL, 1843) in Elazığ Keban Reservoir, East Anatolia Region IV, Aquaculture and Fisheries Symposium, Erzurum, Turkey.

5. Mol S, Özden Ö, Oymak SA (2010) Trace metal contents in fish species from Atatürk Dam Lake 


\section{International Journal of Zoology and Animal Biology}

(Euphrates, Turkey). Turk J Fish Aquat Sci 10: 209213.

6. Begum A, Mustafa A, Amin MN, Chowdhury TR, Quraishi SB, et al. (2013) Levels of heavy metals in tissues of shingi fish (Heteropneustes fossilis) from Buriganga River, Bangladesh. Environ Monit Assess 185(7): 5461-5469.

7. Küçük S (2018) Examination of heavy metal accumulation in fishes, Oral presentation,
International Water and Environment Congres, Bursa, Turkey.

8. Maharajan A, Rufus Kitto M, Paruruckumani PS, Ganapiriya V (2016) Histopatology biomarker responses in Asian sea bass, Lates calcarifer (Bloch) exposed to copper. The Journal of Basic and Applied Zoology 77: 21-30.

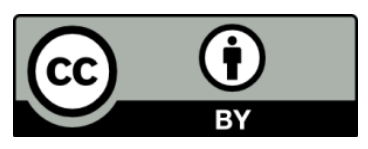

